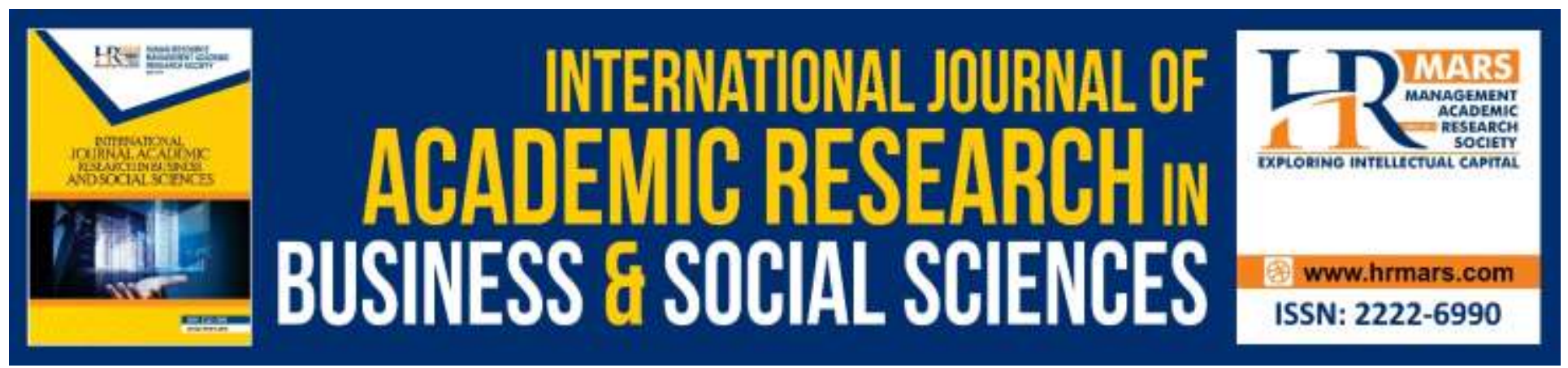

\title{
The Orientalist Mind on the Lazy Malays Stereotype: Is it True?
}

Nur Aqilah Rojudin and Salmah Jan Noor Muhammad

To Link this Article: http://dx.doi.org/10.6007/IJARBSS/v10-i4/7107

DOI:10.6007/IJARBSS/v10-i4/7107

Received: 15 February 2020, Revised: 01 March 2020, Accepted: 19 March 2020

Published Online: 09 April 2020

In-Text Citation: (Rojudin \& Muhammad, 2020)

To Cite this Article: Rojudin, N. A., \& Muhammad, S. J. N. (2020). The Orientalist Mind on the Lazy Malays Stereotype: Is it True? International Journal of Academic Research in Business and Social Sciences, 10(4), 6272.

Copyright: (c) 2020 The Author(s)

Published by Human Resource Management Academic Research Society (www.hrmars.com)

This article is published under the Creative Commons Attribution (CC BY 4.0) license. Anyone may reproduce, distribute, translate and create derivative works of this article (for both commercial and non-commercial purposes), subject to full attribution to the original publication and authors. The full terms of this license may be seen

at: http://creativecommons.org/licences/by/4.0/legalcode

\section{Vol. 10, No. 4, 2020, Pg. 62 - 72}

Full Terms \& Conditions of access and use can be found at http://hrmars.com/index.php/pages/detail/publication-ethics 


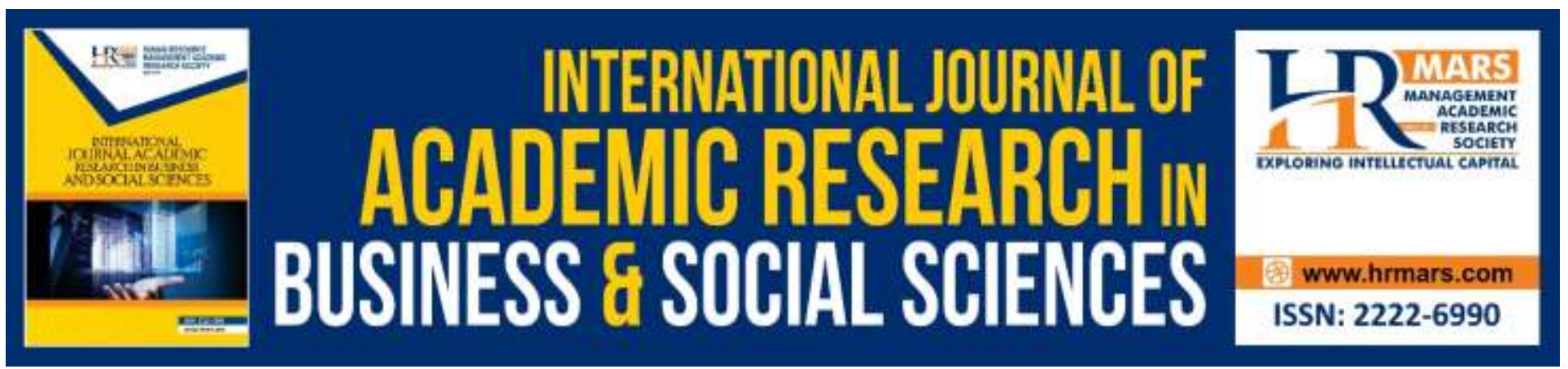

\title{
The Orientalist Mind on the Lazy Malays Stereotype: Is it True?
}

\author{
Nur Aqilah Rojudin and Salmah Jan Noor Muhammad \\ Faculty of Modern Language and Communication, Universiti Putra Malaysia, 43400 UPM Serdang, \\ Selangor \\ Email: nuraqilahmalaysia@gmail.com
}

\begin{abstract}
The Western society hold onto the idea of living by seeing and believing in something logical through scientific proof in an action. Orientalists believe in realism and fully take into account the mind as an alternative of seeking factual knowledge that is clear and correct through thorough and continuous researches. However, this has created a typical stereotype on the characteristics of the Malay society in general. Therefore, this article will be focusing on the view from the Western society towards the Malay society through the typical mind of the orientalists, specifically on the concept of lazy Malays which is very synonymous among the Malay community itself. This research will be using the methods of comparison and content analysis to analyse the stereotype of lazy Malays concept through the mind of the orientalists and the Malays themselves. The results from this research suggested that the given view by the Western society regarding this concept does not entirely meant to be in a negative perspective as there are also positive perspectives given by the Western scholars on Malays' way of living.
\end{abstract}

Keywords: Lazy Malays (Tanah Melayu), Malay, Orientalist, Stereotype, Malay Society.

\section{Introduction}

The stereotype introduced by the Western orientalists back in the old days had given huge impacts on the Malay society up until today. The harsh criticisms and insults toward the Malays have made it seems like there is almost no good thing coming from the people, as well as portraying the Malays negatively in the eyes of the Western society. To the Western orientalists, the Malays were not only seen as a backward society in the aspects of customs and culture, but were also seen to be left behind in the political, economy, culture, and religion aspects. Frank Swettenham, Clifford, Isabella Bird, Emiley Innes and Sir Stamford Raffles, A. Wright, and T.H. Reid were among those who were very critical in giving such opinion. 
Swettenham, Clifford, Bird, Innes and Raffles were among the Western orientalists to voice out their opinions to the whole world regarding the lazy Malays through their writings. The criticisms made had included the lacking of knowledge and wisdom among the Malays in trying to improve their society and ways of living. The criticisms can be found in the writings by Emiley Innes entitled "The Chersonese with the Gilding Off" (1974), Isabella Bird through "The Golden Chersonese And The Way Thither"(1980), and Frank Swettenham's writing "British Malaya: An Account of The Origin And Progress of British Influence in Malay"(1948). Isabella Bird in her writing, suggested that she believed that the Malays were not driven to do anything or to take any action, as well as not being wholeheartedly in completing a task, therefore she deduced that the Malays were lazy. She also added that the Malays were seen to be enjoying more of a leisure lifestyle, and spending most of the time engaging in pointless conversations with friends while having cups of coffee, instead of having any intention of doing something that would benefit their lives as well as giving efforts to change the Malay institution, family and even to change oneself. The common perspectives given by the Western people regarding their stereotype on Malay society are:

i. Malays are left behind in terms of knowledge and economy.

ii. Malays prefer to waste their time by gambling.

iii. Malays love to glorify the rulers.

iv. Malays hardly accept any development brought by the outsiders.

v. Malays are unhygienic.

Stereotype is made when there is a vague explanation and understanding regarding the meaning of stereotype. According to Nancy (2005), stereotype is a concept that refers to the attitude of a particular group of people or society which is created through their social or cultural characteristics in labelling their identity through their attitudes, characteristics, and actions, which give strong impacts on their surroundings. This statement was also supported by Baron, Branscombe and Byrne (2008:188) whom suggested that stereotype is a belief towards the social attitudes or characteristics given. Meanwhile, Powell et. al (2004) suggested that stereotype can also be seen as the tendency of an individual or a society in a group based on their characteristics, and actions. According to McLemore (1994:124) and Healey (2009:110), stereotype is a negative general statement regarding certain ethnic groups, for example the excessive insults of any good or bad attitude directed from an ethnic group to another ethnic group, especially towards the minorities. This can be proven through the clash between two or more ethnic communities. Therefore, it cannot be denied that each ethnic group will have its own sets of stereotypical perspectives towards the others. A clear example is the view given by the Western society towards the Malay society in Tanah Melayu long time ago.

Thus, the perspectives toward the Malay society given by the Western orientalists have about the life of the Malays that the Malay reflect not only the resignation of the Western orientalists, the Malays were not only seen as a backward society in the aspects of customs and culture, but were also seen to be left behind in the political, economy, culture, and religion aspects. Criticism given to the Malays launched by Frank Swettenham, Clifford, Isabella Bird, Emiley Innes and Sir Stamford Raffles, A.Wright and T.H Reid. As a result of the criticism, the study will focus on the Western 
stereotype of submissions related to the Malays in the concept of "lazy Malay". Besides, this research had raised two questions which were 1) Does the lazy Malays stereotype exist among the Malays which is based on the critical and analytical research by the Western people during their invasion and 2) How does the concept of lazy Malays can be changed through the positive perspectives given by the Western and Malay scholars. Therefore, the analysed answers for each question will be provided. There are two objectives in this research which are: 1 ) to identify the Western stereotype towards the laziness of Malays in Tanah Melayu, and 2) to explain on the stereotypical perspectives of Western scholars regarding the concept of lazy Malays in Tanah Melayu. It is rather crucial to develop the questions and objectives in a research to ensure that the research is purposeful as well as making sure the research is guided and went as planned.

\section{Research Methodology}

Research methodology is really important in conducting research to make sure the correct and suitable method is chosen to conduct the research. Therefore, this research had used library research to obtain the data for the research conducted. There were four stages of data collection which were data selection, data collection, data analysis, and data conclusion. It is important to choose the right and most suitable books for this research, as the entire data were obtained from the books in the library. The data collection process for this research was suitable for the research objectives. The content of the book had to be read and understood as well as to be thoroughly analysed and recorded to find its relation with the topic of the research. In the section of data analysis, this stage focused on the information obtained through the selected books which made it the primary data that needed to be further discussed in this research.

\section{Western arguments in creating the lazy Malays stereotype among the Malay society in Tanah Melayu}

Isabella Bird in her writing believed that Malays were not driven to do something and had zero motivation in getting works done, as well as doing job half-heartedly, and this had created a perspective that the Malay society are lazy. She further added that Malays preferred to be enjoying more of a leisure life, and spending most of the time engaging in pointless conversations with friends while having cups of coffee, instead of having any intention of doing something that would benefit their lives as well as giving efforts to change the Malay institution, family and even to change oneself.

Isabella also believed that Malay people preferred entertainment. She said that Malays loved to be in larger groups while doing entertaining activities such as cockfight. She further added that the activity was not only famous among the commoners, but it was also a famous entertainment for the elites. She firmly argued that the activity had finally brought to gambling activity which became a distraction for the Malay rulers.

Isabella also had a negative perception towards the Malay society in food aspects. She noticed that the Malays loved to eat sirih. According to her, those who consumed sirih were seen as unhygienic individuals. This was due to the action of eating sirih that would produce dirty flowing liquid from the mouths, which to her, was like blood flowing out of their mouths. Besides, she believed that eating sirih was an unhealthy habit that would cause the individual's teeth to rot, as 
INTERNATIONAL JOURNAL OF ACADEMIC RESEARCH IN BUSINESS AND SOCIAL SCIENCES Vol. 10, No. 4, April, 2020, E-ISSN: 2222-6990 @ 2020 HRMARS

well as affecting one's health. Isabella also criticized that Malays' daily activity such as plowing the field using the buffalos and cockfight were acts of animal cruelty and inhumane.

The criticisms towards Malay society were further added by Emiley Innes. She argued that the women in the society were seen to be more hardworking than the men in terms of improving the economy level as well as supporting the families. This statement can be found in her writing which argued that women were seen to be doing heavy works like farming, plowing the field, and involving themselves in business to support their families. Men were seen to be involved only in cockfight and spending most of the time in coffee shops and only came home when the night came.

In her book, Emiley further added on the lazy attitude of the Malay royals. This statement was made when she realized that the Royals would instruct the commoners to get the jobs done every time she went to meet the Royals. She also argued that the king or sultan preferred to ask from their people if they wanted something. This was seen as a burden to the people and the Royals would be seen as individuals who could not even manage their own lives. This had tainted the image of Royal institution during that time.

Frank Swettenham (1967) stated that the Malays were moderate, lazy, only wanted to appear attractive, objected any changes, had attitudes of primitive and Muslim fatalists, and believed in superstition.

"Above all, he was a conservative to a degree, is proud and fond of his country and his people, venerates his ancient customs and traditions, fears his Rajas, and has a proper respect for constituted authority-while he looks askance on all innovations, and will resist their sudden introduction. But if he has time to examine carefully, and they are not thrust upon him, he is willing to be convinced of their advantage. At the same time he is a good imitative learner, and, when he has energy and ambition enough for the task, makes a good mechanic."

(Malay Sketches, hlm 3)

Swettenham also stated that the Malays would prefer activities that would waste their time and money such as gambling, and even to the point of making it a daily routine. One of the gambling activities that was famous among the society was cockfight. Swettenham further explained that Malays owned the bad habit of not being driven to work and hardly accepting any changes in development or ideas that were brought by other races. This includes the time when the Western orientalists tried to make some changes in terms of education, for example, trying to build schools. For the Malays, it was unnecessary as they believed that they were already smart if they were proficient in their own language and therefore there was no need of furthering their education for the sake of living. They also believed that it was already enough to understand Malay language without having to learn on how to read and write. Swettenham also added that the Malays were Muslims whom would only follow what was being told to them without learning about the real values brought by the religion, especially when they still believed in superstition. 
However, despite the negative evaluation made by Swettenham, he did not deny the facts that Malays were very much loyal to their rulers and also generous. In his book, Swettenham did not miss his chance of negatively criticizing the Malays for always wasting their money and did not know how to manage their money properly, especially in business. Clifford in 1966 also came with a negative evaluation towards the Malays, whom he would label as lazy. The term 'lazy' would refer to their laziness in working, seeking for knowledge as well as improving their own economic level. This statement would portray the idea that the Malays were too comfortable in managing their lives that they felt that farming would be enough to support their economy without thinking of finding better ways to improve their living. Clifford believed that this was an attitude of someone who had no vision of improving one's life.

Another Western scholar who was being critical towards the Malays was Sir Stamford Raffles. He was once an English lieutenant in Tanah Melayu. Stamford stated that the Malays had no positive and excellent improvement in terms of their intellectual minds. This was due to the weakness of the laws made by the Malays which were not being implemented properly, as well as not being approved by the public. This scenario had made them became lazier in working to support their living. He further added that the Malays were seen to be revengeful and hostile towards other people that criticized them, or even tried to bring peace among them, and this could be clearly portrayed through their attitudes. Raffles also made an insult towards Islam as he described the religion as the religion of the thieves and terrorists, as he viewed the act of punishing those who speak ill of the religion as immoral and cruel.

In a book entitled A History of Classical Malay Literature (1969) written by Winstedt, it was mentioned that those who studied the Malay literary world would find strange elements in Malay literature, and that it would be hard to meet any proof of development and improvement happening in the society. Winstedt further argued that Malay literatures were mostly borrowed and receiving influence from the legendary tales from India. He also emphasized that the minds of the Malays during the colonial era were clouded by foreign literatures, for example the Rome, India and Persian, which were further translated and applied in their own literature. Therefore, Winstedt strongly argued that almost all the facts in Malay writings and literatures came from the Malays who were descended from India, or having connections with Rome. He came to deduce that Malay literatures were not genuinely written from the minds of the Malays as he believed that they were not capable of writing or producing their own literary works.

"When the Malays know how to speak English, the intellectuals were able to become lawyers, even though the courses for the laws were conducted in English and Latin."

(British Malaya: An Account of The Origin And Progress of British Influence in Malay: hIm 5)

Despite the negative comments received from previously mentioned scholars, this scenario could not have happened if Malays would read and study more into the previous researches conducted 
INTERNATIONAL JOURNAL OF ACADEMIC RESEARCH IN BUSINESS AND SOCIAL SCIENCES Vol. 10, No. 4, April, 2020, E-ISSN: 2222-6990 @ 2020 HRMARS

by the local researchers. This would make the Malays to feel even prouder of their own culture and origins. Among the foreign scholars who also criticized the Malays were A. Wrighty and T.H. Reid.

"How unfair the opinion is, after all the proofs provided by the Malay scholars. The foreigners beyond the east side were forced to admit that they (Malay people) refused to do heavy works. They preferred to be involved in cockfight (which is total contradicted to their busy lifestyles)."

(Reid: 1912)

The next scholar would be Tun Dr. Mahathir. He once voiced out in his writing "Dilema Melayu" that Malay people were lazy and hard to change. Mahathir explained on how the Malays were not driven to challenge themselves due to them living in their own comfort zone. He believed that the peninsular has provided enough sources for the Malays to keep on living.

"In short, there were enough food for the whole population throughout the whole year. Starvation which often strike other countries like China, did not happen in Tanah Melayu. In this condition, everyone was safe. Even the weakest and laziest were able to live comfortably, get married and reproduce. In such condition, it is impossible to say that only the fittest would survive. Due to the rich sources of food, even the weakest was able to continue living.

(Dilema Melayu: hlm 25)

Mahathir purposely made such critical remark as a wake-up call for the Malays who have been daydreaming and taking lives for granted for such a long time. However, he noticed that the Malay race is now in an uncomfortable position for receiving pressures and challenges from other races such as the Chinese and the Indian in terms of economy. Commenting on the criticism given to the Malays as the lazy people, Mahathir further provided the reasons and arguments on why such thing would happen in the society. One of the reasons why the Malays are lazy is due to the hot and humid weather in Malaysia which made them develop slow pace of thinking as they would spend most of the time resting at home. However, this reasons is arguable and irrelevant as to compare with our neighbour countries like Singapore and Indonesia. This is because even though both countries have the same tropical climate as Malaysia, both countries are still able to develop.

Therefore, it can now be understood on why the Western scholars would give such critical opinions on Malays. However, it is still surprising how the Malays seem to be taking the criticism and insults lightly although they have read and seen numerous negative remarks about them, but this won't happen for a long time. This is because justice and defence shall be made to protect the value and the culture of the Malays and to make sure the Western society would not be stomping upon the people. 
INTERNATIONAL JOURNAL OF ACADEMIC RESEARCH IN BUSINESS AND SOCIAL SCIENCES

Vol. 10, No. 4, April, 2020, E-ISSN: 2222-6990 @ 2020 HRMARS

\section{Malay and Western scholars' positive stereotype evaluation on the concept of lazy Malays stereotype}

There are few arguments made by the Malay and Western scholars to defend the Malay society from being harshly criticized and insulted by the orientalists and Malay people who were ignorant in trying to learn and know about their own people. Those Malay and Western scholars who had given positive stereotypes in trying to protect the value of Malays were Syed Hussien Al-Attas, Ismail Noor, Muhammad Azaham, and not to forget the Western scholars, Sir Richard Winsted Francois Valentyn and Olaf Winstedt.

Tanah Melayu prominent scholar like Syed Hussien Al-Attas was a scholar who had defended the Malays in his writing entitled Mitos Peribumi Pemalas (1987) in which he rejected the statement on lazy and unhygienic Malays given by the Western scholars. According to him, the label was given to the Malays by the Western people was due to the rejection given by the Malays to them in becoming the slaves to the Western people during the colonization era. The westerners wanted the Malays to become their slaves in their colonial and capitalist business, and even in the local economy system as well. Due to the strong rejection and disobedience given by the Malay people, the Western people were dissatisfied and thus they tried to accuse the Malay people as narrow minded, lazy, unhygienic, and uncivilized. Generally at that moment, Malay people were not that quick witted to analyze the situation. However they already knew the bad intention of the Western people in making them their slaves in business as the Malays knew how their local economy worked, therefore the Western orientalist were trying to seize that opportunity by trying to use the Malays to work for their import and export activities in Tanah Melayu. This situation had raised a dissatisfaction among the Western people who were feeling unease over the rebellious Malays thus throwing insults such as lazy Malays as they decided not to bow down to colonists who wanted to conduct their business there.

According to Syed Hussin Al-Attas, Malay people were given such insult due to their stance of not becoming the slaves to the colonists who were trying to develop the Western economy, and the Malays too did not want to create any business allies with them. For the Malays, those who came to invade Tanah Melayu only wanted to seize the richness of its natural sources. This had caused the colonists to feel furious over the Malays thus they decided to not give any help in developing the local economy of the Malays. Syed Hussin Al-Attas argued that the 'lazy Malays' label that was given was only meant for the unwillingness of the Malays to work for the Western people. He further added that before the arrival of the Western people, the Malays had their own skills such as carpentry, fishing and farming.

In addition, in terms of working, Malay people are resilient, kind, courteous and polite, as well as hygienic. The only time the Malays refused to work with the colonists had unfortunately made them being labelled as the lazy ones. Therefore, it is clear that the accusation indoctrinated by the Western people into others' minds was not because the Malays were lazy in working or getting their jobs done, but rather because they refused to obey the colonists to work as their slaves, as the local saying goes "bagai lembu dicucuk hidung". 
Malay people realized the opportunistic Western people were trying to take advantages of the local people whom they would torture eventually, and therefore it became the reason why they refused to be involved with the Western people. During that time, the 'lazy Malays' concept was just a myth created by the Westerners and spread all around the world, Syed Hussein Al-Attas further added. The Western people should have realized the reasons why Malay people were acting in such ways and that it could be related to the climate, nature and the attitude of the people. He also argued and criticized the writings by the Western scholars who labelled the Malays as lazy. To his understanding, such writings were dishonest and the scholars did not practice the proper ethics in writing. For him, a good piece of writing should portray the writer's love and respect towards his or her people, or even to others as well. Furthermore, the negative evaluation in the writings made by the Western scholars had only shown their refusal to learn more and deeply about the culture and values of the Malay society. In other words, they only saw what was on the surface without trying to dig deeper in trying to understand what caused the Malays to act in certain ways.

However, there were also few Malay scholars whom had praised some Western scholars in giving good and positive reviews about the Malays. Two of the Western scholars who had given positive evaluation towards the Malay society were Sir Richard Winsted Francois Valentyn and Olaf Winstedt. Both scholars had their own perspectives and perceptions in evaluating the Malays. For Sir Richard Winsted, the term 'lazy' should not be given to the Malays. According to Richard, labelling the Malays as 'lazy' was inaccurate as during that time, Malay people had already started working together with the colonists to support their living. Francois believed that the Malay society was made of people who were smart, courteous, polite, artistic, active and talented. The Malays were seen as a group of people who had a great amount of respect to others and it could be seen through their choices of words in voicing out their opinions. Olaf Winsted had also came out with the same comment towards the Malays. He stated that:

"Malay people have the quality of being proud of their own society, which might be almost similar to the proud and great time of the religion of Muhammad once upon a time..."

(Winsted, 1935)

He further added that the Malays should be proud of themselves and to just dismiss the accusations being thrown to them such as lazy, love to gamble and other bad qualities.

\section{Summary}

Both positive and negative opinions given by the orientalists toward the Malays had created a positive stereotype and motivation so that Malay people would always have high level of intelligence to improve themselves, their society and their country and to stop the Western society from giving more false accusations. This is very important to ensure that the Malay society could step forward and stand on the same level as the Westerners in all aspects. When they are driven to improve themselves, the orientalists would no longer be able to accuse and throw their negative stereotype towards the Malays in every aspect. 


\section{Conclusion}

In conclusion, the opinions and evaluations given by the Western people were not all negative. This is because the Western people had finally open their minds upon witnessing the development among the Malays in trying to improve on their education, business, economy, and even in administration. The active involvement of Malays in all areas has finally made the Westerners to change their perspectives towards the Malays and thus include them in their business world. The Western people also realized that Malays too have their own potential in improving themselves, which is totally contradicted to the negative stereotype of 'lazy Malays'. Therefore, Malay people should always be aware and keep in mind that they are not the lazy society who only knew to daydream as they were once told. It is also really important for the Malays to not feeling small in trying to show the world what a great society they really are.

The results of this study are expected to provide additional benefits and contributions to researchers and educational institutions, particularly in the areas of history, anthropology and psychology. In addition, through the writing of the article, the researchers hope this article can give you exposure and insights, the researchers and other educators about the lazy Malays. In fact, researchers hope that this article will not only be read by researchers and educators in the fields of history, anthropology and psychology but will also be read by researchers in other fields. It aims to open people's minds to accept and understand the broad concept of the Malay language in the universal life.

\section{References}

Andi, C. J. (2018). Konsep Nation-State dalam Pemikiran Ideologi Politik Melayu Islam pada Abad Ke-19 M (Studi Pemikiran Abdullah bin Abdul Kadir Munsyi (1787-1854). Jurnal Kebudayaan dan Sastra Islam. Vol. XVIII No. 2, 2018, 139-151.

Emily, I. (1974). The Chersonese With The Gilding Off. Oxford University Press. Kuala Lumpur.

Swettenham, F. A. (1948). British Malaya: An Account of The Origin And Progress of British Influence in Malay. London: G. Allen and Unwin.

Haron, D. (2001). Mantera Melayu: Analisis Pemikiran. Pulau Pinang. Penerbit Universiti Sains Malaysia.

Huge, C. (1927). In Court and Kampong. London: The Richards Press.

Isabella, L. B. (1980). The Golden Chersonese And The Way Thither. Oxford University Press. Kuala Lumpur.

Ishak, S. (2006). Sejarah Sosiobudaya Melayu. Karisma Publication. Shah Alam.

Ismail, H. (1998). Masyarakat dan Budaya Melayu. Kuala Lumpur: Dewan Bahasa dan Pustaka.

Ismail, N. M. A. (2000). Takkkan Melayu Hilang di Dunia. Pelanduk Publication Sdn. Bhd. Selangor.

Kassim, A. (2004). Hikayat Abdulah. Utusan Printcorp Sdn. Bhd. Selangor.

Kassim, A. (1970). Kisah Pelayaran Abdullah. Fajar Bakti. Kuala Lumpur.

Khairun, A. N., \& Nor. A. A. (2014, April 3). Definisi dan Etimologi Melayu. Retrieved from http://karyaagungsem8.blogspot.com/2014/04/definisi-dan-etimologi-melayu.html.

Laurent, M. (2007). Nilai-Nilai Melayu Satu Sudut Pandangan Orang Luar. Penerbitan Universiti Pendidikan Sultan Idris. Tanjong Malim.

Mahathir, M. (1982). Dilema Melayu. Federal Publication. Kuala Lumpur.

Mohd, F. (1980). Kisah Pelayaran Muhammad Ibrahim Munsyi. Dewan Bahasa dan Pustaka Kuala Lumpur. 
INTERNATIONAL JOURNAL OF ACADEMIC RESEARCH IN BUSINESS AND SOCIAL SCIENCES

Vol. 10, No. 4, April, 2020, E-ISSN: 2222-6990 @ 2020 HRMARS

Helmi, E. (2019). Membantah Mitos Melayu Pemalas. Berita The Patriots. Retriever from https://www.thepatriots.asia/membantah-mitos-melayu-pemalas/

Mohd, R. (2014). Pengertian Adat dan Istiadat. Retrieved from http://pelitakaryaagung.blogspot.com/2014/03/pengertian-adat-dan-istiadat.html.

Nik, A. A. (2000). Melayu Di Persimpangan. Edusystem Sdn Bhd.

Syed, H. A. (1989). Mitos Peribumi Malas. Dewan Bahasa dan Pustaka, Kuala Lumpur.

Syed, M. N. A. (1972). Islam Dalam Sejarah dan Kebudayaan Melayu. Kuala Lumpur.

Siti, A. M. (1996). Abdullah Munsyi dan Masyarakat Melayu. Kuala Lumpur. Dewan Bahasa dan Pustaka.

Shamsuddin, M. Y. (1976). Sejarah sastera Melayu moden sesudah tahun 1800. Kuala Lumpur Penerbitan Pustaka Antara.

Solehulhafiz, S. (2019). Orang Melayu Pada Pandangan Inggeris. Berita The Patriots. Retrieved from https://www.thepatriots.asia/orang-melayu-pada-pandangan-inggeris/. 